\title{
Szuhai Ilona
}

\section{Hogyan befolyásolták egyes történelmi időszakok a migráció dinamikáját?}

\section{How certain historical times influenced the dinamics of migration?}

\begin{abstract}
Absztrakt
A népvándorlások mindig fontos szerepet játszottak a világtörténelemben. A fó kérdés, hogy miként határozza meg a történelem a migrációt és hogyan befolyásolja a migráció a történelmet. A migráció dinamikus folyamatát az emberi alkalmazkodás eszközeként tekintik. Korábban a migrációs döntést leginkább a jobb lehetőségek keresése motiválta, a 21. század első évtizedeiben azonban az emberek már olyan közvetlen veszélyek miatt hagyták el otthonukat, mint az éghajlatváltozás különféle hatásai, természeti katasztrófák, az államok gyengülése, országon belüli polgárháborús helyzet, vagyis a gazdasági és a biztonsági stabilitás hiánya. A föld népességének csupán 3,5\%-a, csaknem 272 millió személy érintett a nemzetközi migrációban, azonban ezek a vándorok egyes kontinensekre, régiókra és néhány országra koncentrálódnak. Jelenkori történelmünket a nemzetközi mobilitás jellemzi, a nemzetközi migráció régi-új formái láthatók, mint az ideiglenes vagy a cirkuláris migráció, azonban ezek a jelenségek nem teljesen újak. Párhuzamos mintáik megtalálhatók a fontos történelmi korszakokban.
\end{abstract}

Kulcsszavak: mobilitás, migráció, cirkuláció, világtörténelem, menekültek

\begin{abstract}
Population movements have always played an important role in world history. The main question is how history affects migration and how migration influences history. The dynamic process of migration is considered as a tool for human adaptation. Previously, the migration decision was motivated mainly by looking for better chances, in the first decades of the $21^{\text {st }}$ century people leave their home due to such immediate dangers like various effects of climate change, natural disasters and weakness of states, civil war situation within a country, that is lack
\end{abstract}


of economic and security stability. Although, only 3.5 percent of the world population is concerned in international migration, those migrants are concentrated on certain continents, regions and some countries. Mobility is the main character of our contemporary history. However, the new old types of international migration can be seen, like temporary or circular migration, but these phenomena are not really new. We can find their parallel patterns in important historical times.

Keywords: mobility, migration, circulation, world history, refugees

„A migráció története maga a világtörténelem”

Russell King

\section{Bevezetés}

A migráció mindig fontos és állandó része volt a világtörténelemnek, illetve a civilizáció kialakulásának. Ma a nemzetközi migráció egyre fontosabb szerepet játszik minden társadalmi, gazdasági, demográfiai és kulturális összefüggésével együtt. Korunk migrációs jelenségei mögött mély történelmi folyamatok húzódnak meg (Cseresnyés, 2005, 40.). A történelmi korokban lezajlott vándorlások dinamikájának feltárása hozzásegíthet a jelenlegi és a jövőbeli migrációs minták változásának megértéséhez. Az a tény jelzi ennek fontosságát, hogy napjainkban közel 272 millió ember vesz részt a nemzetközi vándorlásban. Ebben a migrációs környezetben kell feltárni és elemezni a tömeges népmozgások demográfiai, gazdasági és kulturális hatásait, valamint megtalálni a kényszermigráció és a nemzetközi védelemre szorulók helyét. A nemzetközi migráció zürzavaros évei után, ebben a kölcsönösen összekapcsolt és egymástól függő világban, könnyü megfeledkezni arról, hogy az egész migrációs jelenség hogyan is kezdődött, hogyan vált az emberi vándorlás természetes folyamata egy összetett, dinamikus és sokrétü jelenséggé. Az emberi evolúció szoros kapcsolatban van az egyik helyről a másikra vándorlással, valamint az új környezethez való alkalmazkodással. Russell King megállapítása, mely szerint az ember vándorló faj ma is igaz (King, 2008, 8.). Nincs még egy olyan élölény, amely történelmi léptékben mérve időben és térben ilyen gyorsan, ilyen messzire eljutott volna, mint az ember. A migrációt általános eszközként használták arra, hogy alkalmazkodjanak a kockázatok és a lehetőséges egyenlőtlen elosztásához, ami a mai világunkban általánosnak tekinthető (Donato-Massey, 2016, 8.). Russell King szerint a migráció maga a világtörténelem, ezért a közelmúlt globális migrációs jelenségeinek is lehetnek történelmi párhuzamai. 
Példaként kiemelhetjük azokat az afrikaiakat, akik ma életük kockáztatásával, kishajókkal próbálnak átkelni a Földközi-tengeren, hogy eljussanak Európába. King szerint ezek az emberek őseik több millió éves vándorútját ismétlik, amikor azok Észak-Afrikából északra, Eurázsia felé vándoroltak (King, 2008, 8.). Más szavakkal, a történelem tükröt tart mai világunk elé, azonban sokszor nem tanulunk a múlt leckéiböl. A mai migrációs folyamatok különböznek a régi vándorlásoktól, ezért gondolhatjuk úgy, hogy ezek a jelenségek új kihívásokat jelentenek a világ számára. A régi kihívások azonban megjelenhetnek új köntösben, ha felgyorsulnak és a korábbi problémáknál intenzívebbé válnak, így újnak tủnhetnek (Rada, 2016, 1.). Ha ezt az elmúlt évtizedek migrációs folyamataira vetítjük, akkor az látható, hogy történelmi folyamatossága ellenére a vándorlás felgyorsult és szerteágazóbb lett. A tömeges vándorlás sem új vagy kivételes történelmi jelenség, hiszen a térbeli mobilitás a modern társadalmak jellegzetessége (Cseresnyés, 2005, 64.). A népességnövekedésre, a környezeti és az éghajlatváltozásra, illetve a gazdasági szükségletekre adott válaszként a népmozgások mindig az emberi történelem részét képezték (Castles, 2000, 273.). A migráció és a történelem kapcsolata dinamikus. A migráció formálta a történelmet és a történelem megteremtette a körülményeket a migráció különféle formáihoz. Vagyis a migráció a történelem része és a történelem a migráció része (IOM, 2004). Kutatók szerint napjaink migrációs folyamatainak megértéséhez párhuzamos vándorlásokat találhatunk a történelemben. Érdemes ezért tanulmányozni a migráció jellemző vonásait és dinamikáját a jelentős történelmi időszakokban. Ahogy Demetrios G. Papademetriou megjegyezte, a világtörténelem a görög kolóniáktól és a római katonai hódításoktól a bizánci és az oszmán birodalomig tele van a migráció korszakaival (Papademetriou, 2003, 39.). Ez a tanulmány nem elemzi a világtörténelem minden korszakának vándorlási változását, csupán néhány - szubjektív módon kiválasztott - jelentôs történelmi időszak vándorlási mintáját emeli ki, ismertetve azok jellemző vonásait és dinamikáját. A fó kérdés, hogy miként határozza meg a történelem a migrációt és hogyan befolyásolja a migráció a történelmet. A tanulmány bemutatja továbbá a nemzetközi migráció jelenlegi helyzetét a rendelkezésre álló legfrissebb adatok alapján.

\section{Migrációelméleti fogalmak}

A migrációelméletben napjainkban is izgalmasnak tünik a kérdés, hogy milyen emberi tevékenység feleltethető meg a migráció meghatározásának (Hautzinger, 2018, 11.), illetve milyen módon nevezhetünk migránsnak egy személyt. 


\section{Nemzetközi migráció}

Először fontos tisztázni a migráció és a nemzetközi migráció fogalma közötti különbséget. A szakirodalomban a vesztfáliai békeszerződést tekintik a választóvonalnak. Ez alapján elkülöníthető az emberi vándorlás, amely a történelem előtti időktől létezik és a nemzetközi migráció, amelyröl a független és szuverén nemzetállamok sérthetetlenségén alapuló nemzetközi jogi rendszer kialakítása, 1648 óta beszélhetünk (Teitelbaum, 2009, 116.). Az ENSZ migrációs ügynöksége, a Nemzetközi Migrációs Szervezet (International Organization for Migration - IOM) hivatalos definíciója alapján a nemzetközi migráció azt a folyamatot jelenti, amelynek során a személyek elvándorolnak a szokásos tartózkodási helyükről és átlépik egy olyan ország nemzetközi határát, amelynek nem állampolgárai (IOM, 2019a, 111.).

\section{Nemzetközi migráns}

Az IOM definíciója szerint a nemzetközi migráns olyan személy, aki az állampolgársága szerinti országon kívül tartózkodik. Hontalan személy esetén a születési vagy a szokásos tartózkodási helye szerinti államot kell érteni. Ez a meghatározás azokat a migránsokat foglalja magában, akik tartósan vagy ideiglenesen kívánnak vándorolni, akik szabályosan, a megfelelő okmányok birtokában utaznak, valamint a szabálytalan (irregular) helyzetben lévőket is. Statisztikai szempontból viszont más kritériumok alapján határozzák meg a nemzetközi migránst. Az ENSZ Nemzetközi Migrációs Statisztikákra vonatkozó ajánlásai szerint a nemzetközi migráns olyan személy, aki megváltoztatta szokásos tartózkodása szerinti országát. A dokumentum különbséget tesz az úgynevezett rövid idejü migráns és a hosszú idejü migráns között. Előbbi legalább három hónapra, de kevesebb, mint egy évre, utóbbi legalább egy évre változtatja meg a tartózkodási országát. Problémát okoz viszont, hogy nem minden ország követi ezt a definíciót, közülük néhány más kritériumok alapján kategorizálja a nemzetközi migránsokat, például azzal, hogy eltérő minimális tartózkodási időt alkalmaz. Az országok közötti eltérések a definíciókban, valamint az adatgyüjtés módszereiben ezért megnehezítik a nemzetközi migránsokra vonatkozó nemzeti statisztikák teljes összehasonlíthatóságát (IOM, 2019b, 110).

\section{Elüzött személyek (displaced persons)}

Az IOM hivatalos definíciója szerint az elüzött olyan személy vagy emberek csoportja, aki vagy amely arra kényszerült, hogy elmeneküljön vagy el- 
hagyja otthonát, illetve szokásos tartózkodási helyét, akár nemzetközi határ átlépésével, akár egy országon belül, különösen fegyveres konfliktus, általános erőszak, az emberi jogok megsértése, természeti vagy ember által okozott katasztrófa eredményeként, vagy ezek hatásainak elkerülése érdekében (IOM, 2019b, 53).

\section{Szezonális migráció}

A szezonális migráció általában évszakokhoz kötötten, az év meghatározott időszakában jellemző, minden évben ismétlődő munkavégzésre irányul, például termények betakarítása, zöldségek, gyümölcsök szüretelése. Ekkor egy rövid időszakra nagy létszámú munkaerőre van szükség. A munka befejezése után az emberek elhagyják a munkavégzés országát. A jelenlegi európai uniós szabályozás szerint a szezonális munkavállalás nem lehet hosszabb tizenkét hónapon belül hat hónapnál.

\section{Ideiglenes és cirkuláris migráció}

Az ideiglenes migráció egy ,sajátos motiváció vagy cél érdekében megvalósitott vándorlás azzal a szándékkal, hogy azt követöen a személy visszatérjen a származási országába, vagy továbbvándoroljon. Cirkuláris migráció, amikor egy személy ismételt legális vándorlás folytat két vagy több ország között." (Gulyás, 2018, 80.) E két meghatározás alapján, valamint a két fogalom különbségeire tekintettel az ideiglenes migráció inkább egy egyszeri mozgásra, majd egy meghatározott idejű tartózkodásra utal az Európai Unióban, míg a cirkuláris migráció egy oda-vissza vándorlást jelent az EU és a származási ország között, amely lehetővé teszi a migráns számára, hogy újra belépjen a fogadó országba egy későbbi időpontban (European Commission, 2011.). Illés Sándor és Kincses Áron meghatározása szerint „a nemzetközi cirkuláris migráció többszöri visszatérö mozgásokból áll ugyanazon térbeli rendszerben" (Illés-Kincses, 2012, 197.). Talán a fentiekből is látható, hogy a migrációs minták éles elhatárolása sokszor nem egyszerü, a mozgástípusok egymással összekapcsolódnak, illetve átalakulnak. Azok a többes jelenségek is bonyolítják a helyzetet, amelyre Illés és Kincses hívta fel a figyelmet, vagyis a többes identitás, a többes állampolgárság, valamint a többes lakóhely (Illés-Kincses, 2009, 733.). Ezek a jelenségek sem ritkák ma már a globalizáció világában. 


\section{Migrációs minták}

Ismeretes, hogy a nemzetközi migráció nem egységes a világ minden részén, hiszen formálják a gazdasági, földrajzi, demográfiai és egyéb tényezők, melyek különféle migrációs minták kialakulását eredményezik, s úgynevezett migrációs folyosók vagy korridorok alakulnak ki. A legfontosabb regionális mintázatok sokszor évtizedek vagy évszázadok alatt alakulnak ki, és megmutatják, hogy az emberek hogyan és hová vándorolnak a nemzetközi térben (IOM, 2019a, 2.). A legnagyobb folyosók a fejlődő országokból a nagyobb gazdaságok felé irányulnak, úgy mint az USA, Franciaország, Oroszország, az Egyesült Arab Emirátusok és Szaúd-Arábia. Megemlíthetjük azonban a közismert Németország-Törökország migrációs korridort is (Szuhai, 2018, 87.). Az ENSZ elemzése szerint ezek a minták valószínűleg még hosszú ideig megmarad a jövőben, főként azért, mert néhány fejlődő régióban és országban a népesség várhatóan növekedni fog az elkövetkezendő évtizedekben, így a migrációs nyomást a jövő generációk is érzékelni fogják (UN DESA, 2019, 2.).

\section{Az írott történelem előtti migráció}

Az emberiség vándorlástörténete az emberiség születéséig, hétmillió évre nyúlik vissza, amikor az első majomszerü őseink előbukkantak az afrikai erdőkből és benépesítették a szavannát. A barlanglakó előember Kelet-Afrikában élt ötmillió évig, majd egy másik emberszabású jelent meg, amely már nagyobb távolságokat mert megtenni. A Homo erectus benépesítette egész Afrikát és elkezdte felfedezni a világot. Végül a Homo sapiens ugyanabban a kelet-afrikai bölcsőben fejlődött ki 150 millió évvel ezelőtt (King, 2008, 15.), vándorlása során pedig meghódította az egész világot eljutva Kelet-Ázsiába és Ausztráliába mintegy 50.000 évvel ezelőtt, Észak-Európába 40.000 éve, Amerikába mintegy 12.000 éve és a legtávolabbi csendes-óceáni szigetekre mintegy 2.000 évvel ezelött (Donato-Massey, 2016, 7.).

\section{A hódítások kora}

Valószínüleg nincs a földön olyan nemzet, amelyik mindig ugyanazon a helyen élt a történelem során, hiszen a népvándorlások fontos szerepet játszottak minden nemzet történelmében. Az írott történelem a legkorábbi időktől kezdve igazolja a gyakori népmozgásokat. Később gyakorivá váltak a még összetet- 
tebb népességcserék a túlélési szükségletekre vagy a demográfiai változásokra, a politikai környezetre, illetve a katonai stratégiára adott válaszként (IOM, 2004 , 9.). A középkor időszakában kiterjedt vándorlások zajlottak. A 8. századtól kezdve a vikingek szerte Európában portyáztak és több helyen letelepedtek (Normandia, Észak-Anglia, Skócia és Î́rország). A normannok később elfoglalták az angolszász királyságokat, Írország nagy részét, Dél-Olaszországot és Szicíliát. A 8. században a muszlim arabok, a berberek és a mórok megszállták Ibériát új királyságokat alapítva, magukkal hozva egy letelepedési hullámot Észak-Afrikából. A keresztes hadjáratok során az európai keresztény hadseregek elfoglalták Palesztinát a 11. és a 13. század közötti időszakban, megalapítva három keresztény királyságot, ahol letelepítették a keresztény lovagokat. A 14. században a német katonai telepesek letelepedtek a Baltikumban, ahol közülük került ki az uralkodó elit (URL1). Csak néhány példa arra, hogy sok esetben a migráció volt a katonai hódítás következménye.

\section{Migráció Európában, Afrikában és Ázsiában}

A kora újkorban az Európán belüli erősödő migráció magában foglalta egyrészt a monarchiák által toborzott föld nélküli munkaerőt, hogy a néptelen, vagy megmüveletlen régiókban letelepedjenek, másrészt a vallási üldöztetés által elöidézett kényszervándorlást is. ${ }^{1}$ A 14 . századtól a szerbek kezdték elhagyni középkori királyságukat és birodalmukat, amelyet elárasztottak az oszmán törökök, és északra vándoroltak, a mai Vajdaság területére, amely abban az időben a Magyar Királysághoz tartozott. Megemlíthető még a munkaerő toborzása Írország ültetvényeire, illetve az angol protestáns telepesek írországi letelepítése 1560 és 1690 között, továbbá a németek toborzása Oroszországba, amikor Nagy Katalin letelepítette őket a Volga környékén a 18. században (URL1). A 17. és a 18. században a munkások életében megszokottá vált a szezonális és a cirkuláris migráció. Afrikát tekintve a népmozgások gazdag története megelőzte a gyarmati időszakot. Jellemző volt a szezonális és a cirkuláris migráció a mezőgazdaság, vadászat vagy állattenyésztés, a nagyobb biztonság elérése, a megélhetés biztosítása, valamint a természeti katasztrófa és háború elől menekülés, továbbá kereskedelem és zarándoklat céljából. Ázsiában mindig fontos

1 Ez a jelenség a protestánsok tömeges vándorlását jelentette Spanyol-Németalföldröl a Holland Köztársaságba 1580 után, továbbá a zsidók és a moriszkók kiutasítását Spanyolországból az 1590-es években, valamint a hugenották kiutasítását Franciaországból az 1680-as években. A moriszkók az Ibériai-félsziget keresztény visszahódítása után a muzulmán hitet elhagyó mór újkeresztények és leszármazottaik voltak. 
szerepet játszott a kereskedelem az emberek mobilitásában. Az arab és a kínai kereskedők a jól bejáratott tengeri utakon utaztak a Maláj-félszigetre és az indonéz, illetve a fülöp-szigeteki szigetvilágba. Voltak bevált kereskedelmi útvonalak Indiába, az Arab-félszigetre és Nyugat-Afrikába is. A cirkuláris migráció volt a kovácsok és a művészek (akrobaták, énekesek) életének általános jellemzője. Kisebb csoportokban utaztak Dél-Ázsián belül (URL2).

\section{A nagy földrajzi felfedezések kora}

Az új világok felfedezése Amerikában és Ázsiában több mint ötszáz évvel ezelött nemcsak az európai felfedezők számára jelentett fordulópontot, hanem a migráció történelme szempontjából is döntő fontosságú volt. A tengerentúli migrációt főként kereskedelmi és stratégiai tényezők befolyásolták, és ez öszszekapcsolta a kontinenseket (IOM, 2004, 10.). Az európai iparosítás és a globális kapitalizmus 1800 és 1929 között egy újabb tömeges migrációs korszakot eredményezett. A becslések szerint csaknem 50 millió ember vándorolt ki sürün lakott iparosodó európai országokból gyéren lakott iparosodó országokba Amerika és Óceánia térségében. A kivándorlók csaknem 60\%-a az USA-ba vándorolt, a többiek Argentínába, Ausztráliába, Brazíliába, Kanadába és Új-Zélandra mentek (Donato-Massey, 2016, 8.). Az európai kivándorlók a szegénység és az országuk politikai elnyomó rezsimje elől menekültek el, emellett új gazdasági lehetőségek is motiválták őket az új világban (URL3). A Délkelet-Ázsiába, az Indiai-óceán és a Csendes-óceán déli részén található területekre irányuló migrációban több mint 29 millió indiai és 19 millió kínai vett részt. A legtöbb vándorlás Indiából a gyarmatokra irányult a brit birodalmon keresztül (McKeown, 2004, 157.). Katharine Donato és Douglas S. Massey megfogalmazása szerint az európai hatalmak gyarmati törekvése Amerikában, Afrikában és Ázsiában a modern kor tömeges emberi migrációjának egyik jelentős korszaka volt, összefüggésben a globális gazdasági változás időszakával, valamint a világkereskedelem kialakulásával. Egyes európai országok (Britannia, Franciaország, Németország, Spanyolország és Portugália) elősegítették állampolgáraik külföldi letelepedését (Donato-Massey, 2016, 8.). Az új ipari technológiák megjelenése, a termelési eszközök gépesítése és az ipari tevékenység megszilárdítása következményeként rengeteg embernek kellett elhagynia otthonát. A 15. századtól kezdődő időszak jellemzője tehát az volt, hogy az európai nemzetállamok kialakulása, a gyarmatosítás és az iparosítás a migráció gyors növekedéséhez vezetett (Castles, 2000, 273.). Egyéb tényezők pedig megteremtették a megfelelö feltételeket a példanélküli tengerentúli migrációhoz, úgy mint a részletes 
és megbízható földrajzi ismeretek, pontos térképek készítése, új technológiák bevezetése a navigációs eszközök, valamint az óceáni hajózás terén: nagyobb, biztonságosabb és gyorsabb tengeri hajók készítésével (vitorlás, gőzhajó) (IOM, 2004, 10.). A 19. századot az európai tömeges tengerentúli vándorlások korának nevezik. A gyarmatosítással kapcsolatban meg kell említenünk a rabszolgaságot. Az ültetvények kialakítása az új gyarmatokon egyre több munkaerőt igényelt, egy teljesen újfajta nemzetközi migrációt alakult ki, hiszen a rabszolga-kereskedelem egybeesett a munkaerőhiánnyal. Egyes kutatók szerint ebben az időszakban, 1550-ben kezdődött a modern munkaerő migráció (IOM, 2004, 10.), hiszen a rabszolga-kereskedelem az emberi történelem egyik legnagyobb tömeges munkaerő vándorlása, valamint legnagyobb arányú kényszermigrációja volt. A becslések szerint több mint 10 millió afrikait szállítottak el kényszerrel, fơként Nyugat-Afrikából Amerikába, rabszolgaként. A tömeges rabszolga-kereskedelmet csupán a 19. században tiltották be Afrikában, több európai országban, Amerikában és a gyarmatokon (URL2).

\section{Migráció a 20. században}

Az emberi migráció összetettebbé és sokrétübbé vált a 20. században. Új migrációs mintaként a menekültek vándorlása vált jelentőssé a 20 . század első felében. Az 1879 és 1938 közötti időszakot a háború és a politika által előidézett nagy vándorlás korszakának tekintik, azonban ez a fajta migráció egyre inkább jellemző volt az egész 20. századra. A több etnikumú Habsburg, Oszmán és Romanov birodalom széthullásával párhuzamosan a nemzetállamok a 19. század végén és a 20. század elején érték el csúcspontjukat. Az oszmán birodalom felbomlása és a háború Oroszországgal 4-6 millió ember cseréjét eredményezte: a muszlimok a Balkánról, Görögországból és Oroszországból délre, Törökországba vándoroltak. A keresztények viszont más irányba indultak. Közel egymillió örményt utasítottak ki Törökországból, 400.000 zsidó pedig Palesztinába vándorolt (McKeown, 2004, 163.). A transzatlanti migráció látványos csúcsot ért el 1913-ban, évi 2,1 millió vándorral. A Délkelet- és Észak-Ázsia felé irányuló migráció szintén példa nélküli csúcsot ért el 1911 és 1913 között, évi 1,1 millió migránssal. A globális kapitalizmus tömeges vándorlási folyamatait azonban 1914-től kezdődően az első világháború akadályozta. Adam McKeown megállapította, hogy a globális migráció új csúcsokat ért el az 1920-as években. A transzatlanti migrációban évi 1,2 millió migránst regisztráltak 1924-ben, ezt követően az USA bevándorlási kvótát vezetett be, jelentősen csökkentve ezzel a dél- és kelet-európai migrációt. Ázsia esetében 
évi 1,25 millió vándor érkezett Délkelet-Ázsiába 1927-ben, 1929-ben pedig 1,5 millió migránst regisztráltak Észak-Ázsiában (McKeown, 2004, 167.). Az első világháború önmagában menekültek millióit hagyta hátra. A 20. század első felében közel 10 millió európai polgári személy menekült el, vagy kényszerrel szállították őket munkavégzésre, gyakran a halálba a születési országuktól eltérő országban lévő (koncentrációs) táborokba. A háború utáni nemzetállamok etnikai tisztogatásba kezdtek. Az állampolgárság és a személyazonosító dokumentumok bevezetésével a belépési szabályok még szigorúbbá váltak, továbbá fokozódott a katonai szolgálat és nemzet iránti lojalitás megkövetelése (Lüthi, 2010, 3.). Nem volt ritka az állampolgárság visszavonása sem (Vajkai, 2017, 138.). Az első világháborút követően az észak-atlanti világnak már nem volt szüksége több ipari munkásra, ráadásul globális szinten is visszaszorult a munkaerő migráció. A nemzetközi vándorlás két világháború közötti csökkenésének oka részben a gazdasági stagnálás, a politikai zürzavar, az általános bizonytalanság és a biztonság hiánya volt. 1930-ban, a gazdasági visszaesés idején a migráns munkásokra versenytársként tekintettek a helyiek és felerősödött velük szemben az idegengyülölet. A célországok kormányai erre a belépési szabályok szigorúbb ellenőrzésével, illetve a külföldiek munkalehetőségeinek csökkentésével reagáltak (IOM, 2004, 14.). Erre az időszakra az otthonukból elüzött személyek, a menekültek, illetve a közép- és kelet-európai új kommunista rezsimek elől menekülők mobilitása volt jellemző (Lüthi, 2010, 4.). Stephen Castles szerint a nemzetközi migráció fö tényezőként jelent meg a társadalmi átalakulásban az egész világon a 20. század második felében (Castles, 2000,269 .). A második világháborút gyakran fontos vízválasztóként emlegetik a migráció történelmében, amely a modern kor legnagyobb kényszervándorlását okozta. „Becslések szerint a harcok európai befejezésekor a kontinensen legalább 40 millió menekült volt. Ezen felül több millió kényszermunkás és egyéb kényszermigráns tartózkodott a volt Német Birodalom területén, majd további több millió német nemzetiségü lakost telepitettek ki kelet-európai országokból." (Klenner, 2019. 18.). Egy részük Nagy-Britanniába, Belgiumba, Franciaországba és Hollandiába került, illetve sokan részt vehettek az USA, Kanada, Ausztrália és Argentína által indított migrációs programokban (IOM, 2004, 14.). Ebben az időszakban a háború utáni helyreállításhoz munkaerőre volt szükség Európában, illetve a gazdasági fellendülés idején Észak-Amerikában és Ausztráliában. A nyugat-európai iparosodott országok 1945 és 1973 között változó intenzitással igényelték az ideiglenes munkaerőt. A korábbi karibi és dél-ázsiai gyarmatokról származó migránsok munkát kerestek Britanniában, a török munkavállalók Európa több országába, főként Németországba mentek vendégmunkásnak, a korábbi francia gyarmatokról, Észak-Afrikából 
sokan Franciaországba vándoroltak (URL2). A második világháború után a nagyhatalmak összefogtak, hogy új multilaterális intézményeket hozzanak létre, amelyek fenn tudják tartani a békét, ugyanakkor elősegítik a globális kereskedelmet és a beruházásokat. Ez a globalizációs folyamat fokozatosan fejlődött Európa és Japán háború utáni újjáépítésével, majd felgyorsult a hetvenes éveket követően, a digitális forradalom kirobbanásával, amely egy új, tudásalapú gazdaságot hozott létre. Kína bekapcsolódásával 1979-ben, majd a Szovjetunió összeomlásával 1991-ben egy valódi globális gazdaság alakult ki. Az európai gazdaságok lassan növekedésnek indultak, ennek hatására lelassult a kivándorlás Európából, ugyanakkor a munkások számára előnyösek voltak az újonnan teremtett munkalehetőségek Németországban, Franciaországban, Belgiumban és Svájcban (Donato-Massey, 2016, 9.). Megállapítható tehát, hogy a 20. század második felét sokféle nemzetközi vándorlás, főként az ideiglenes munkaerő migráció jellemezte. Ezek közül néhány még ma is jellemző a migrációs folyamatokra, úgy mint az üldöztetés, a visszatérés, a dekolonializáció, a munkaerő migráció és a menekültek migrációja (Cseresnyés, 2005 , 66.). Stephen Castles és Mark Miller a 20. század végét a migráció korának nevezte, föként a migráció növekvő politikai vonása miatt. A nemzetközi migráció átpolitizálása mellett megállapították annak néhány általános tendenciáját, amely szerint a migráció globalizált, felgyorsult, szerteágazó és feminizált lett (Castles-Miller, 2003, 7.).

\section{Migráció a 21. század elején}

A nemzetközi migráció jelentősége tovább növekedett a 21. században, minthogy a népesség mobilitása intenzívebbé vált és új formákat öltött. A migráció, mint a társadalmi változás egyik fontos tényezőjének jelentősége abban rejlik, hogy egyes országokra és régiókra koncentrálódik (Castles, 2000, 275.). Stephen Castles, Hein de Haas és Mark J. Miller szerint a migránsokat kibocsátó-befogadó országok dichotómiája mára megkopott, ugyanis ma már a legtöbb ország megtapasztalja mind a kivándorlást, mind a bevándorlást (Castles-Haas-Miller, 2014,14 .). A mobilitás új formájaként a nyugdíjas migráció, a jobb életforma keresése, az ismételt és a cirkuláris vándorlás jelent meg. Sok helyen továbbra is a családegyesítés maradt a legnagyobb arányú vándorlás célja a munkavállalás és a tanulmányok folytatása mellett. Kialakultak a migrációs hálózatok, amelyek összekötik a származási és a célországokat. A migráció megváltoztathatja a demográfiai, gazdasági és társadalmi struktúrát, létrehozhat új kulturális sokféleséget (Castles-Haas-Miller, 2014, 7.). 


\section{A nemzetközi migráció jelenlegi helyzete}

A migráció a 21. századra könnyebben megvalósítható lett, mint korábban, részben a digitális forradalomnak, az infokommunikációs technológiák és a közlekedés fejlődésének, részben az utazási költségek csökkenésének és a globalizációnak köszönhetően. Míg a migráció kiváltó okai alapvetően változatlanok maradtak, addig azok a körülmények, amelyek között az emberek meghozzák a döntést a vándorlási lehetőségeikkel kapcsolatban, jelentősen megváltoztak Számos tényező erősíti a migrációt: a gazdasági jólét, egyenlőtlenség, demográfia, erőszak és konfliktus, valamint a környezeti változás (IOM, 2017, 13., 168.). Mindezek mellett a 21. században elötérbe került a gyengülő és a törékeny államok problematikája. Azok az államok, amelyek nem tudják ellátni klaszszikus funkcióikat, köztük a gazdasági és a biztonsági stabilitás megteremtését az állampolgáraik számára, vagy a határok védelmét, azok tömeges migrációt okozhatnak, gyengítve ezzel a szomszédos országokat, az egész régiót, majd távolabbi országokat és kontinenseket is (Szuhai, 2015, 99.). Russell King magyarázata szerint a „migrációs érem” két oldala a migráció, illetve a helyben maradás. Az érem első oldala hangsúlyozza a migráció alapvető történelmi szerepét, mint az emberi tapasztalat részét a távoli múlttól a jelenen keresztül tovább a jövő felé. A migrációs érem másik oldala más szempontból tekint a migrációra, hiszen ma a világ népességének csupán 3,5\%-a tekinthető nemzetközi migránsnak, tehát a népesség döntő többsége, 96,5\%-a valószínüleg továbbra is a születése szerinti országban él (King, 2012, 5.). Gunnar Malmerg ezt a jelenséget ,immobilitási paradoxonnak” nevezte. Arra az ellentmondásra irányította a figyelmet, hogy az emberek nagy többsége nem vándorol, ellentmondva annak, amit a bérkülönbségek vonzó és taszító tényezőin alapuló közgazdasági modellek jósolnak (Malmerg, 1997, 21.). Az érem migrációs oldalát vizsgálva a következőkben láthatjuk a nemzetközi migrációval kapcsolatban rendelkezésre álló legutóbbi adatokat az IOM 2020. évi globális migrációs jelentése alapján (IOM, 2019b). A jelenlegi becslések szerint 2019-ben csaknem 272 millió személyt tekintettek nemzetközi migránsnak. ${ }^{2}$ Ez azt jelenti, hogy a világ népességének 3,5\%-a nem a születése szerinti országban élt. A nemzetközi migránsok száma fokozatosan emelkedett az elmúlt közel ötven évben, ahogy azt az 1. számú táblázat bemutatja ötéves periódusokra bontva, kivéve a 2015 és 2019 közötti időszakot.

2 Az elmúlt 49 évben nem mindig adott minden ország információt, ezért a táblázatban bemutatott adatok tájékoztató jellegủek. 


\begin{tabular}{|c|c|c|c|}
\hline Év & $\begin{array}{c}\text { A világ népessége } \\
\text { (milliárdra kerekítve) }\end{array}$ & $\begin{array}{c}\text { Nemzetközi migránsok } \\
\text { száma }\end{array}$ & $\begin{array}{c}\text { Nemzetközi } \\
\text { migránsok aránya (\%) }\end{array}$ \\
\hline 1970 & 3,7 & 84460125 & 2,3 \\
\hline 1975 & 4,0 & 90368010 & 2,2 \\
\hline 1980 & 4,5 & 101983149 & 2,3 \\
\hline 1985 & 4,9 & 113206691 & 2,3 \\
\hline 1990 & 5,3 & 153011473 & 2,9 \\
\hline 1995 & 5,7 & 161316895 & 2,8 \\
\hline 2000 & 6,1 & 173588441 & 2,8 \\
\hline 2005 & 6,5 & 191615574 & 2,9 \\
\hline 2010 & 7,0 & 220781909 & 3,2 \\
\hline 2015 & 7,4 & 248861296 & 3,4 \\
\hline 2019 & 7,7 & 271642105 & 3,5 \\
\hline
\end{tabular}

1. számú táblázat: A nemzetközi migránsok becsült száma és aránya a világ népességéhez viszonyítva, 1970-2019. Forrás: IOM UN Migration, 2019b

Az ENSZ adatait elemezve az látható, hogy 1970-től 1980-ig a világ népessége és a nemzetközi migránsok száma fokozatosan növekedett, míg a migránsok aránya viszonylag stabil maradt. Az 1980-as évek második felétől a népesség fokozatosan tovább növekedett, azonban a migránsok száma gyorsabban nőtt, mint az azt megelőző ötéves periódusban. Ennek oka a világ politikai helyzetében keresendő. Ez a növekvő tendencia folytatódott 2019-ig.

Az 1970-es becsült adatokhoz képest a nemzetközi migránsok száma több mint háromszorosára nőtt. Az elmúlt 19 évben, 2000 óta pedig közel 100 millióval növekedett a számuk. Ez a növekedés gyorsabb volt, mint ahogy azt a korábbi elörejelzések jósolták, 2005 után az arányuk átlépte a három százalékot. Ma a világon minden harmincadik ember nemzetközi migránsnak tekinthető. A nagyobb régiókat ${ }^{3}$ összehasonlítva az adatokból az látható, hogy Ázsiában volt a legtöbb, 84 millió nemzetközi migráns, majd Európa következett 82 millióval. Ez azt jelenti, hogy az összes nemzetközi migráns 61\%-a e két kontinensen élt. Észak-Amerikában közel 59 millió, Afrikában csaknem 27 millió, Latin-Amerikában és a karibi-térségben mintegy 12 millió, Óceániában pedig 9 millió nemzetközi migráns élt. Ha ezeket a számokat a régiók teljes népességére vetítjük, akkor az látható, hogy ez az arány Óceániában volt a legnagyobb, 20\%, majd Észak-Amerikában 16\%, Európában pedig 11\%. A többi régióban ez az arány

3 Az ENSZ Gazdasági és Szociális Ügyek Föosztálya (UN DESA) által meghatározott hat földrajzi világrégió. 
alig éri el a 2\%-ot (IOM, 2019b, 24.). A regionális eltérések, az összetettség és a fejlemények tanulmányozása fontos szempontokat nyújtanak a migrációs folyamatok megértéséhez. A migrációs mintákat tekintve jelentős különbségek láthatók a régiók között: Afrikában a migráció túlnyomórészt régión belüli volt (egyik afrikai országból a másikba), ugyanakkor más régióba is irányult a vándorlás (afrikai országból nem afrikai országba). Ezzel szemben Latin-Amerikában és a karibi-térségben a migrációra a más régiókba, különösen Észak-Amerikába irányuló kivándorlás volt jellemző. Itt a régión belüli vándorlás csak kis szerepet játszott (IOM, 2019b, 122.). Melyik ország a legnépszerübb úti cél a nemzetközi migránsok számára? Az adatokból kiderül, hogy 2019-ben is az USA volt a fó célország és ez a tendencia 1970 óta töretlen. Az USA mellett Németország, Szaúd-Arábia, Oroszország és az Egyesült Királyság volt népszerü. A nemzetközi migránsok több mint fele (141 millió) Európában és Észak-Amerikában élt. Honnan származott a nemzetközi migránsok többsége 2019-ben? Az összes migráns több mint 40\%-a Ázsiából származott: Afganisztán, Banglades, India, Kína és Pakisztán. India volt a legnagyobb kibocsátó ország 2019-ben, a második helyen Mexikó állt, majd Oroszország következett. Több európai országból vándoroltak ki nagy arányban: Egyesült Királyság, Lengyelország, Németország és Ukrajna (IOM, 2019b, 25-26.). Globálisan tekintve fontos hozzátenni azt is, hogy sokan nem jutottak el úti céljukhoz. 2014 és 2018 között 30 900 ember vesztette életét, miközben egy másik országba próbált eljutni. Ezek közül 17.919 a Földközi-tengerben lelte halálát (IOM, 2019b, 32.).

\section{Menekültek és menedékkérök}

2018 végén összesen 25,9 millió menekültet tartottak nyilván a világban, ebből 20,4 millió az ENSZ mandátuma alapján volt elismert menekült, 5,5 milliót pedig az ENSZ Közel-keleti Palesztin Menekülteket Segélyező és Munkaközvetítő Hivatala (United Nations Relief and Works Agency for Palestine Refugees - UNRWA) regisztrált a Közel-Keleten. Jóllehet, 2012 óta az összes menekült éves növekedési aránya lelassult, mégis a 25,9 millió az eddigi legmagasabb szám. A teljes nemzetközi menekültállomány 52\%-a 18 év alatti volt (IOM, 2019b, 39.). A menedékkérők számát 3,5 millióra becsülték 2018-ban. Ezek a személyek már benyújtották a menedékjogi kérelmüket, azonban még nem született meg a döntés a menekült státuszuk ügyében. A legtöbb menedékjogi kérelmet az USA-ban nyújtották be, ami 254.300 új kérelmet jelentett. Peruban nyújtották be a második legnagyobb arányú kérelmet, 192.500, föként venezuelai állampolgárok. Ezután Németország következett 161.900 kérelemmel. A korábbi évekhez hasonlóan a menedékkérők számát nagyban befolyásolták 
a válságövezetek megoldatlan vagy kiújult konfliktusai. Érdemes kiemelni, hogy 2018-ban az ENSZ mandátumában elismert menekültek föbb származási országa a következő volt: Szíria, Afganisztán, Dél-Szudán, Mianmar, Szomália, Szudán, Kongói Demokratikus Köztársaság, Közép-afrikai Köztársaság, Eritrea és Burundi. Ezek a menekültek alkották a teljes menekültállomány 82\%-át (IOM, 2019b, 39-40.).

\section{Összefoglalás}

A népvándorlások jelensége az őskortól napjainkig mindig a történelem része volt a demográfiai növekedésre, az éghajlatváltozásra, a társadalmi, politikai és gazdasági változásokra adott elsődleges válaszként. Az elmúlt öt évszázadban a tömeges migráció fontos szerepet játszott a gyarmatosításban, az iparosításban, a nemzetállamok kialakulásában, valamint a kapitalista világpiac kialakulásában (Castles-Haas-Miller, 2014, 48). Összegzésként megállapítható, hogy a migráció az emberi alkalmazkodás egyik alapvető eszköze, amelyet gyakran a veszélyek elkerülésére és a lehetőségek megszerzésére használtak a történelem során, hiszen a politikai, a gazdasági, a jogi és a kulturális lehetőségek egyenlőtlen elosztása jellemző a világban. A jobb lehetőségek keresése jellemezte a 20. század utolsó és a 21. század első évtizedének mobilitását, azonban Massey szerint változás körvonalazódik a nemzetközi migráció motivációiban és tendenciáiban (Massey, 1988). Ezek a változások az éghajlatváltozás és a növekvő polgári erőszak miatt következnek be. Tehát az emberek a jobb lehetőségek keresése helyett az olyan közvetlen fenyegetések miatt indulnak el, mint a polgári összecsapások, bünözés, a háborús helyzet, családi erőszak, természeti katasztrófák, politikai felkelések és gazdasági katasztrófák. Ezeket az előrejelzéseket alátámasztják a nemzetközi szervezetek adatai, akik hasonló elvándorlási okokra hívják fel a figyelmet: szegénység, egyenlőtlenség, fejletlen gazdaság, a sivatagosodás, a vízhiány, az államok meggyengülése, az instabilitás, az emberi jogok megsértése, a konfliktusok és erőszak, illetve katasztrófák. A becsült adatok szerint e két utóbbi tényező miatt 41,3 millió ember kényszerült arra, hogy elhagyja otthonát országán belül (IOM, 2019b, 43.). Mindezek mellett az is tapasztalható, hogy az emberi mobilitás struktúrája többrétüvé vált: tervezett migráció, áttelepítési programok. A migráció egy olyan dinamikus folyamat, amelynek alakulását nehéz előrelátni. A kutatók mégis mindig a jövő változásait szeretnék megtudni vagy megjósolni. Castles, Haas és Miller megállapítása szerint a nemzetközi migráció a globális változás egyik legfontosabb tényezöje. Véleményük szerint a következő okok miatt nevezhetjük történelmünket továbbra is a migráció korának: 
- „az egyes országok közötti gazdasági egyenlötlenség miatt a migrációs hajlandóság növekszik és az emberek jobb életszinvonalat keresnek

- a világszerte zajló politikai és etnikai konfliktusok tömeges migrációt eredményeznek és növelik a nemzetközi védelemre szoruló emberek számát

- az új szabadkereskedelmi övezetek elösegitik a munkaerö migrációját." (Castles-Haas-Miller, 2014, 7.).

Mindehhez hozzátehetjük, hogy szinte minden országot érinti a nemzetközi migráció vagy annak hatása, ezért a jelentős demográfiai különbségek, a globális Észak és a globális Dél közötti gazdasági egyenlőtlenségek, a politikai nézetkülönbségek, az emberi jogok megsértése továbbra is megosztja a világot, mégis többen lesznek, akik nem vándorolnak el a hazájukból. Az előrejelzések szerint a világ népessége a jövőben is növekedni fog, az áru, a tőke és a szolgáltatások globális integrációja, valamint a regionális válságok továbbra is nagy vándorlásokat generálnak, ezért a nemzetközi migránsok aránya is nagyobb lesz. Jelenkori történelmünket a nemzetközi mobilitás jellemzi, a nemzetközi migráció régi-új formái láthatók, úgy mint az ideiglenes migráció vagy a cirkuláció, azonban ezek a jelenségek nem teljesen újak. Párhuzamos mintáikat megtalálhatjuk a nemzetközi migráció fontos történelmi korszakaiban.

\section{Felhasznált irodalom}

Castles, S. (2000): International migration at the beginning of the twenty-first century: global trends and issues. International Social Science Journal, 52, 269-281. DOI: 10.1111/14682451.00258

Castles, S. - Haas, H. de - Miller, M. J. (2014): The Age of Migration International Population Movements in the Modern World. Fifth Edition. New York: The Guilford Press

Castles, S. - Miller, M. J. (2003): The age of migration. International population movements in the modern world. Third edition. New York: Palgrave Macmillan

Cseresnyés F. (2005): Migráció az ezredfordulón. Budapest-Pécs: Dialóg Campus

Donato, K. - Gabaccia, D. (2015): From the Slavery Era to the Global Age. Gender and International Migration. New York: Russell Sage Foundation.

Donato, K. - Massey, D. S. (2016): Twenty-First Century Globalization and Illegal Migration. ANNALS, AAPSS, 666, 1, 7-26. DOI: 10.1177/0002716216653563

European Commission (2011): Temporary and Circular Migration: Empirical Evidence, Current Policy Practice and Future Options in EU Member States. Luxembourg: Publication Office of the European Union

Gulyás É. (szerk.) (2018): Migráció és a bevándorlókhoz való viszony Németországban és Magyarországon. Győr: Széchenyi István Egyetem, Deák Ferenc Állam- és Jogtudományi Kar, 80. 
Hautzinger Z. (2018): A migráció és a külföldiek büntetöjogi megjelenése. Pécs: AndAnn Kiadó Illés S. - Kincses Á. (2012): Hungary as receiving country for circulars. Hungarian Geographical Bulletin, 3, 197-218.

Illés S. - Kincses Á. (2009): Migráció és cirkuláció. Statisztikai Szemle, 7-8, 729-747.

IOM (2004): Essentials of Migration Management: A Guide for Policy Makers and Practitioners. Geneva: IOM

IOM The UN Migration Agency (2017): World Migration Report 2018. Geneva: IOM

IOM UN Migration (2019a): Glossary on Migration. Geneva: IOM

IOM UN Migration (2019b): World Migration Report 2020.

King R. (2008): Vándorló emberiség. Budapest: Geographia Kiadó

Klenner Z. (2019): A menekültügy története. In: Klenner Z. (szerk.) (2019): Menekültügyi ismeretek. Budapest: Dialóg Campus Kiadó, 16-38.

Lüthi, B. (2010): Migration and Migration history. Potsdam: Zentrum für ZeithistorischeForschung

Malmerg, G. (1997): Time and Space in International Migration. In: Hammar et al. (ed.): International Migration, Immobility and Development. Multidisciplinary Perspectives. Oxford: Berg, 21-48.

Massey, D. S. (1988): International migration and economic development in comparative perspective. Population and Development Review, 3, 383-414. DOI: 10.2307/1972195

McKeown, A. (2004): Global Migration. Journal of World History, 2, 155-190. DOI: 10.1353/ jwh.2004.0026

Papademetriou, D. G. (2003): Managing Rapid and Deep Change in the Newest Age of Migration. The Political Quarterly, 1, 39-58. DOI: 10.1111/j.1467-923X.2003.00580.x

Rada P. (2006): Atalakuló biztonsági kihivások. Budapest: Grotius Kiadó

Szuhai I. (2015): Rethinking the concept of failed states. Central European Papers, 2, 99-110. DOI: $10.25142 /$ cep.2015.020

Szuhai I. (2018): A németországi török diaszpóra kialakulása és migrációjának dinamikája. In: Gulyás É. (szerk.) (2018): Migrációs és a bevándorlókhoz való viszony Németországban és Magyarországon - Tanulmányok. Győr: SZE Deák Ferenc Állam- és Jogtudományi Kar Jogelméleti Tanszék, 77-90.

Teitelbaum, M. S. (2009): The Global Commission on International Migration: Challenges and Paradoxes. The Center for Migration Studies Special Issues, 1, 116-124. DOI: 10.1111/j.2050411X.2009.tb00419.x

Vajkai E. (2017): Az állampolgárságtól megfosztás Franciaországban. Magyar Rendészet, 3, 131-146.

\section{A cikkben található online hivatkozások}

URL1: Human Migration. https://www.newworldencyclopedia.org/entry/Human_migration URL2: GreeNet. www.striking-women.org 